\title{
PROFESSIONAL TRAINING METHODOLOGY OF SPECIALISTS TRAINING AT BORDER UNIT
}

\section{МЕТОДИКА ПРОФЕСІЙНОЇ ПІДГОТОВКИ ФАХІВЦІВ У ПРИКОРДОННОМУ ПІДРОЗДІЛІ}

\section{Valentina Miroshnichenko ${ }^{1}$}

DOI: https://doi.org/10.30525/978-9934-588-38-9-9

Abstract. The subject of the study is the professional training methodology of specialists training at border unit. The purpose of the article is to develop and substantiate the professional training methodology of specialists training at border unit. The following research tasks were formulated: to find out the current state of development of the problem of research in pedagogical theory; to clarify the essence of the concept of "professional training of specialists at the border unit"; to develop and substantiate the methodology of specialists training at border unit.

The theoretical (analysis, synthesis, comparison, generalization, systematization) and empirical (questionnaire, interview, direct and indirect observation, study of positive experience of professional training of specialists at border units) methods were used to achieve the goal and to solve the set tasks. The research methodology involved their complex use at different stages of the research.

Professional training of specialists at the border unit is interpreted as a system of organizational, educational and pedagogical measures aimed at the formation and development of border guards with professional skills, theoretical knowledge and practical skills, which should ensure the unit's high readiness to actions, and their coordination and high professionalism at the state border protection.

The basis of the professional training of border guards is the principle: "Each border guard is personally responsible for the level of his profes-

\footnotetext{
${ }^{1}$ Doctor of Pedagogical Sciences, Associate Professor, Head of the Pedagogy and Social and Economic Disciplines Department, National Academy of the State Border Guard Service of Ukraine named after Bohdan Khmelnytskyi, Ukraine
} 
sional skill and the quality of the performance of duties according to his position." The themes of the classes are determined by taking into account the tasks assigned to the unit, the conditions of a particular region, the location of the unit and the organizational and staff structure.

The professional training of border guards of different categories is conducted in the following areas: practical training (personal safety and use of force, physical training, fire training, environmental safety of the state border, tactical medicine); theoretical training (development of subjects of distance learning or individual lists of questions); legal training in the areas of activity (legal bases of the activity of the border service, legal bases of operational and search activity, bases of international law, bases of criminal and criminal procedural law, bases of legislation on administrative responsibility, bases of criminalistics, etc.); military and ideological training.

The methodology is considered by the author as a set of methods of professional training of specialists. At the same time, methods of professional training (studying) are a set of techniques and methods for training conducting of specialists at the border unit, by means of which knowledge is transferred and assimilated, skills and high moral and psychological qualities necessary for performing operational and operational tasks in the state border protection and ensuring the coherence of the units. The main methods of professional training (studying) of specialists at the border unit include the following: narration, explanation, conversation, demonstration (illustration), exercise (training), practical work, independent work.

Forms of specialists training in the border guard division are as follows: complex practical classes, trainings, drilling, direct training, role-playing games, information, and self-training, mentoring activities, training at meetings, training courses in training centres and during the courses of multiplication. The main form of the professional training of specialists at the unit, which directly protects the state border, is a comprehensive (practical) training.

The development and justification of the methodology of professional training of specialists at the border unit helps to improve its theoretical and practical aspects. 


\section{1. Вступ}

Події останніх років, а саме анексія Криму, збройна агресія Російської Федерації на Сході України, втрата контролю над частиною кордону в межах Донецької і Луганської областей, прийняття під охорону та оборону ділянки в зоні розмежування - все це змінило і загартувало прикордонників. 3 одного боку, саме прикордонники першими стали на захист нашої держави та народу і зараз мужньо й самовіддано виконують свій професійний обов'язок. 3 іншого боку, значно зросли вимоги суспільства до професіоналізму прикордонників.

Запорукою виконання завдань з охорони державного кордону персоналом будь-якого прикордонного підрозділу є його професійна підготовка. Для реалізації себе як фахівця, професіонала у будь-якій сфері діяльності кожній людині як суб'єкту діяльності необхідно пройти курс професійної підготовки. У нашому дослідженні зупинимось на вивченні та аналізі професійної підготовки фахівців у прикордонному підрозділі.

До персоналу прикордонного підрозділу відносять як офіцерів, так і військовослужбовців строкової військової служби, і військовослужбовців, які проходять службу за контрактом (далі - фахівці).

Як зазначає О. Татарін, «професійна діяльність фахівців прикордонної служби - це діяльність з охорони й оборони державного кордону України. Громадяни, які проходять військову службу в ДПСУ, є військовослужбовцями ДПСУ (далі - військовослужбовці). Оскільки кожен військовослужбовець, обіймаючи певну посаду, виконує обов'язки відповідно до того чи іншого фаху, можливим, на нашу думку, буде застосування терміна «фахівці прикордонної служби» [1, с. 28-29].

Метою статті є розроблення та обгрунтування методики професійної підготовки фахівців у прикордонному підрозділі. Було сформульовано такі науково-дослідницькі завдання: з'ясувати сучасний стан розробленості проблеми дослідження у педагогічній теорії; уточнити сутність поняття «професійна підготовка фахівців у прикордонному підрозділі»; розробити та обгрунтувати методику професійної підготовки фахівців у прикордонному підрозділі.

Для досягнення мети і вирішення поставлених завдань використано теоретичні (аналіз, синтез, порівняння, узагальнення, систематизація) та емпіричні (анкетування, бесіда, пряме і непряме спо- 
стереження, вивчення позитивного досвіду професійної підготовки фахівців у прикордонних підрозділах) методи дослідження. Методологія дослідження передбачала їх комплексне застосування на різних етапах дослідження.

\section{2. Теоретичні основи дослідження}

Теоретичну основу нашого дослідження становлять праці В. Бабич, А. Вихруща, Є. Долинського, О. Діденка, О. Ставицького, предметом вивчення яких є підготовка фахівців до певного виду діяльності. Висновки та положення зроблені цими та іншими вченими мають велику наукову цінність для 3'ясування теоретичних та практичних аспектів зазначеної проблематики.

Цікаві підходи до підвищення ефективності підготовки до професійної діяльності військовослужбовців містяться у дисертаційних дослідженнях А. Галімова (підготовка до виховної роботи з особовим складом), А. Мельнікова (підготовка до фізичного виховання), В. Гащука (деонтологічна підготовка), В. Ягупова (підготовка до віійськово-професійної діяльності) та інших.

Щодо ідей удосконалення системи підготовки молодших фахівців прикордонної служби з урахуванням зарубіжного досвіду, зокрема США та країн Європейського Союзу, суттєве значення має науковий доробок А. Балендера, Т. Тронь, Н. Ринденко, В. Беркій, І. Блощинського. Дослідники доходять висновку, що «добір форм та методів професійної підготовки фахівців визначається ідеологією практичного використання набутих вмінь та навичок у професійній діяльності. На перший план виходять практичні заняття, які імітують ситуації реального життя та особливостей служби на кордоні, що дає змогу відпрацювати такі сценарії у ході навчання» [2, с. 363]. Саме такий підхід у розумінні методики професійної підготовки фахівців-прикордонників було взято нами за основу.

Однак в цих та інших працях в прямій постановці не порушувалась проблема методики професійної підготовки фахівців у прикордонному підрозділі.

В «Енциклопедії професійної освіти» зазначається, що «професійна підготовка характеризується сукупністю оволодіння особистістю спеціальними знаннями, уміннями, навичками, необхідними якостями, 
надбанням трудового досвіду і норм поведінки, які забезпечують можливість успішної праці за обраною професією [3, с. 390].

Вікіпедія трактує професійну підготовку як «здобуття кваліфікації за відповідним напрямом підготовки або спеціальністю, як цілеспрямований процес навчання наявних і потенційних працівників професійних знань та вмінь з метою набуття навичок, необхідних для виконання певних видів робіт» [4].

У монографії С. Долинського знаходимо визначення В. Семиченко, що «це поняття розкривається в двох аспектах:

як навчання - деякий спеціально організований процес формування готовності до виконання майбутніх завдань;

як готовність - наявність компетенції, знань, умінь та навичок, необхідних для успішного виконання певної сукупності завдань» [5, с. 14].

Ми поділяємо думку Г. Алєксєєвої, що «професійна підготовка - це система організаційних і педагогічних заходів, які забезпечують формування в особистості професійної спрямованості, загальних і професійних знань, умінь і навичок і професійної готовності» [6].

Професійна підготовка фахівців у прикордонному підрозділі це система організаційних, навчально-педагогічних та практичних заходів, спрямованих на формування і розвиток у прикордонників професійно необхідних якостей, теоретичних знань та практичних навичок, що мають забезпечити високу готовність підрозділу до дій, їх злагодженість та високий професіоналізм в охороні державного кордону [7, с. 131].

Професійна підготовка фахівців прикордонної служби здійснюється згідно з вимогами законів України «Про Національну безпеку», «Про Державну прикордонну службу України», «Про вищу освіту», Концепції інтегрованого управління кордонами, Директиви «Про забезпечення національної безпеки на державному кордоні України» та інших керівних відомчих документів.

\section{3. Результати дослідження}

Як було з'ясовано під час дослідження, основу професійної підготовки прикордонників становить принцип: «Кожен прикордонник персонально відповідає за рівень своєї професійної майстерності та якість виконання обов'язків за посадою». Керівники усіх рівнів орга- 
нізовують та забезпечують підготовку підпорядкованого персоналу за відповідними напрямами службової діяльності на рівні, який забезпечить готовність фахівців прикордонного підрозділу до успішного виконання завдань за призначенням. Також керівники забезпечують належні умови для самостійної підготовки фахівців.

Виокремлюючи напрямки професійної підготовки фахівців у прикордонному підрозділі, доречно урахувати думку О. Ставицького , що «для осмислення напрямів реформування освіти 3 метою підготовки фахівця до дій у суспільстві постійних трансформацій методологічно важливо запровадити новий підхід до освіти, який на основі інтеграції всіх попередніх підходів дасть змогу формувати та розвивати професіоналізм майбутнього прикордонника, акцентувати увагу саме на перетворювальній діяльності» [8, с. 50].

Щодо тематики занять, то вона визначається урахуванням покладених на підрозділ завдань, умов конкретного регіону, дислокації підрозділу та організаційно-штатної структури.

Структура професійної підготовки фахівців містить практичні заняття та тренування, які проводяться на ділянці кордону з опрацювання варіантів дій прикордонного підрозділу в ситуаціях, що виникають чи можуть виникнути в реальній обстановці. Планування професійної підготовки фахівців здійснюється заступником командира прикордонного підрозділу з персоналу на підставі відповідних програм та відомчих наказів.

Головними завданнями планування професійної підготовки персоналу прикордонної служби є такі:

забезпечення управлінського впливу на підвищення рівня боєготовності і боєздатності військовослужбовців та їх підготовки до виконання завдань із охорони та захисту державного кордону;

визначення конкретних заходів професійної підготовки відповідним керівним структурам щодо порядку і термінів їх виконання;

забезпечення доцільного, економічного використання сил та засобів [9].

Відповідно до керівних документів професійна підготовка прикордонників різних категорій проводиться за такими напрямками:

практична підготовка (особиста безпека та застосування сили, фізична підготовка, вогнева підготовка, екологічна безпека державного кордону, тактична медицина); 
теоретична підготовка (опрацювання тематики дистанційного навчання або індивідуальних переліків питань);

правова підготовка за напрямами діяльності: правові основи діяльності прикордонної служби, правові основи оперативно-розшукової діяльності, основи міжнародного права, основи кримінального та кримінального процесуального права, основи законодавства про адміністративну відповідальність, основи криміналістики, основи роботи 3 іноземцями та діяльності, пов'язаної з реадмісією осіб, правові основи інформаційно-аналітичної діяльності; статути Збройних Сил України;

військово-ідеологічна підготовка.

Безпосередня підготовка до служби включає перевірку теоретичних знань та вирішення ввідних за різних ситуацій. Підготовка на збоpax та курсах підвищення кваліфікації проводиться відповідно до розпоряджень Адміністрації Державної прикордонної служби України та наказів вищого керівництва.

У відділах (відділеннях) професійної підготовки органів охорони державного кордону складаються індивідуальні переліки питань на електронних носіях усіх фахівців різних категорій.

Індивідуальні переліки питань містять матеріал спеціальної та загальної підготовки, вимог нормативно-правових угод, актів, якими регламентується або який впливає на порядок здійснення оперативно-службової діяльності, для фахівця, який обіймає конкретну посаду.

Методику ми розглядаємо як сукупність методів професійної підготовки фахівців. Водночас, методи професійної підготовки (навчання) це сукупність прийомів і способів доцільного проведення тренування фахівців у прикордонному підрозділі, за допомогою яких, здійснюється передача та засвоєння знань, формування у фахівців навичок i високих морально-психологічних якостей необхідних для виконання оперативно-службових завдань 3 охорони державного кордону та забезпечення злагодженості підрозділів [10].

До основних методів професійної підготовки (навчання) фахівців у прикордонному підрозділі відносимо такі: розповідь, пояснення, бесіда, показ (демонстрація), вправа (тренування), практична робота, самостійна робота.

Відомо, що розповідь - це образне, живе, емоційне і послідовне оповідально-описове викладення навчального матеріалу з метою 
повідомлення фактів, опису подій та явищ. Тому розповідь, як правило, використовується під час вивчення об'єктивних процесів і закономірностей, закладених у зразках озброєння, технічних засобах охорони державного кордону, практичних дій окремих прикордонників, а також їх спільних дій у складі прикордонних нарядів для виконання завдань $з$ охорони державного кордону. Розповідь як метод професійної підготовки повинна мати пізнавальну та виховну спрямованість, давати тільки достовірні та науково обгрунтовані факти, містити достатню кількість прикладів, які доводять обгрунтованість викладених положень, мати чітку логіку викладення. На практиці, розповідь часто поєднується 3 поясненням, інструктажем й демонстрацією, інформуванням.

Інформування - це діяльність керівного складу прикордонного підрозділу щодо надання фахівцям необхідної для оперативно-службової діяльності суспільно-політичної, оперативно-тактичної, правової, соціально-побутової та іншої інформації.

Пояснення $є$ оповідально-інформаційним викладенням матеріалу, пов'язаним з аналізом і тлумаченням вимог нормативних документів 3 питань оперативно-службової та повсякденної діяльності, вимог щодо порядку діяльності, формуванням у фахівців патріотичних якостей, свідомого розуміння та сприйняття відомчих принципів і норм, культури служби та поведінки. Тому в процесі навчання велике значення має пояснення. Під час підготовки до занять, керівник повинен готуватися до відповідей на можливі запитання, що дасть змогу зробити пояснення коротким та доступним.

Оскільки бесіда як метод професійної підготовки (навчання) складається з обговорення фахівцями прикордонного підрозділу установлених керівником питань 3 подальшим підбиттям підсумків заняття, iii використання відбувається для систематизації, поглиблення, закріплення, контролю засвоєння знань, формування у фахівців прикордонного підрозділу уміння точно та стисло висловлювати свої думки, обгрунтовувати ті чи інші положення. Бесіда передбачає, що зміст теми значною мірою вже відомий фахівцям, або близький до їх життєвого чи набутого в процесі охорони державного кордону досвіду.

Важливим методом професійної підготовки є показ (демонстрація). Цей метод застосовується для формування у прикордонників 
правильних уявлень про зміст положень, які вивчаються, виконання тієї чи іншої дії або прийому. Показ полягає у зразковому виконанні фахівцями дії чи прийому, демонстрації техніки, озброєння, епізодів дій підрозділів, кінофільмів, схем та інших наочних засобів. Навчання за цим методом спирається на властиву людині здатність до наслідування, тобто точного повторення сприйнятої дії.

Ефективним методом засвоєння та формування у персоналу прикордонного підрозділу особистісних ділових умінь і навичок, навчання їх виконання (дотримання) відомчих стандартів прикордонної служби на практиці є рольова гра або RPG (англ. Role-playing game). Методика проведення рольових ігор визначена в «Методичних рекомендаціях щодо порядку проведення рольових ігор з персоналом відділів прикордонної служби», який залучається до несення служби в пунктах пропуску через державний кордон.

Вправа (тренування) - це планомірно організоване, свідомо осмислене багаторазове повторення певних дій і прийомів, що ускладнюються, 3 метою формування, закріплення та вдосконалення у персоналу практичних навичок і вмінь. Під час вправ прикордонники опановують практичні дії щодо застосування зброї та технічних засобів охорони державного кордону, обслуговування техніки. Цей метод застосовується для того, щоб навчити фахівців (окремого прикордонника, підрозділ) використовувати одержані знання з різних напрямів (предметів) підготовки на практиці. Вправи $є$ основою практичного навчання фахівців. У ході навчання використовують індивідуальні, групові та тренувальні вправи.

Індивідуальні вправи застосовуються з метою вироблення у фахівців прикордонного підрозділу умінь і навичок, необхідних для якісного та ефективного виконання професійних обов'язків. Вони характеризуються тим, що окремі прикордонники під керівництвом начальника відділу (заступника начальника відділу) або самостійно на підставі завдання виконують одні й ті ж дії, (наприклад, виконують якийсь норматив з обслуговування технічних засобів охорони кордону) для доведення цих дій до рівня автоматизму (вироблення навичок).

Групові вправи застосовуються з метою вироблення у тих, хто навчається, умінь і навичок у колективних діях і становлять основу практичного навчання прикордонних підрозділів, їх злагодження для 
виконання завдань з охорони кордону. Методика проведення групових вправ передбачає, що вони проводяться, як правило, на місцевості та характеризуються тим, що кожен фахівець виконує дії відповідно до свого професійного призначення.

У підрозділах, які безпосередньо охороняють державний кордон, основним шляхом підтримання, розвитку й удосконалення навичок та вмінь $\epsilon$ тренувальні вправи, тобто свідоме, багаторазове повторення засвоєного прийому (дії) з поступовим ускладненням умов його виконання і нарощування фізичного і морального навантаження. У результаті цього вдосконалюється професійна майстерність фахівців.

Вправи виконуються як на спеціальних заняттях, так і попутно, під час виконання будь-яких завдань за функціональним призначенням або з охорони державного кордону. Прикордонники можуть виконувати вправи, діючи зі зброєю або без неї. Закінчуються вправи підбиттям підсумків. При цьому даються оцінки дій кожного фахівця та вказівки щодо подальшого вдосконалення навичок й умінь.

Ще одним методом є практична робота. Вона являє собою виконання фахівцями прикордонного підрозділу дій у реальних умовах практичної діяльності з охорони державного кордону протягом тривалого часу 3 метою подальшого вдосконалення знань, умінь і навичок. У ході дій керівник здійснює управління діяльністю фахівців, дає необхідні поради, спонукає прикордонників працювати з повним напруженням сил. Після виконання плану керівник підбиває підсумки відпрацювання завдань, вказує на причини недоліків.

Заняття, що проводяться методом практичної роботи, допомагають не тільки поглибити знання, вдосконалити вміння й навички, але й виявити недоліки, слабкі місця у підготовці окремих фахівців. Керівник повинен детально вивчити всі помилки, які виявляються під час практичної роботи, з'ясувати їх причини та допомогти кожному прикордоннику їх усунути.

Важливу роль відіграють інноваційні методи професійної підготовки фахівців у прикордонному підрозділі. Інноваційне навчання передбачає створення, поширення нових методів і засобів (нововведень) для розв 'язання проблем організації охорони кордону, які вирішуються звичними, традиційними методами, а також результат творчого пошуку нестандартних розв 'язань різноманітних проблем: нові 
технології, оригінальні дидактичні ідеї, форми і методи навчання, охорони кордону.

Не менш важливими методами професійної підготовки є самостійне вивчення навчального матеріалу та самосійне виконання практичних дій, що передбачають перегляд, читання (за необхідності - конспектування) рекомендованої літератури відповідно до індивідуальних переліків питань, тренування щодо визначення та розподілу завдань, виконання різних прийомів, дій тощо. 3'ясовано, що ці методи є одними 3 основних методів підготовки персоналу відділу прикордонної служби, укомплектованого військовослужбовцями за контрактом.

Під формою професійної підготовки (професійного навчання) розуміється організаційна сторона процесу підготовки фахівців, що відображає в першу чергу, склад фахівців, структуру заняття, місце проведення, тривалість заняття, характер дій як керівника заняття, так і тих, фахівців, з якими воно проводиться. Форма навчання являє собою інтеракцію - взаємодію керівників та підпорядкованого персоналу під час опрацювання певного навчального матеріалу. У прикордонному підрозділі форми навчання залежать від специфіки навчання, змісту матеріалу, вимог, які пред'являються до підготовки фахівців та підрозділу в цілому, організаційної структури підрозділу та інших факторів.

Формами підготовки фахівців у відділі прикордонної служби є такі: комплексні практичні заняття, тренування, тренінги, безпосередня підготовка до служби, рольові ігри, інформування, самостійна підготовка, заходи наставництва, підготовка на зборах, курсах підвищення кваліфікації в навчальних закладах (центрах) та під час проведення курсів мультиплікації.

Основною формою професійної підготовки фахівців у підрозділі, який безпосередньо охороняє державний кордон, є комплексне (практичне) заняття. Під час комплексних (практичних) занять фахівці отримують практику з виконання своїх посадових обов'язків в умовах реальної оперативно-службової обстановки, яка склалась на кордоні, керівники прикордонних підрозділів та їх заступники удосконалюють і закріплюють свої теоретичні знання, отримують практику в управлінні підрозділом і удосконалюють свої уміння в організації оперативно-службових дій з охорони державного кордону. 
3 метою формування у фахівців високих моральних якостей та психологічної стійкості, комплексні практичні заняття повинні проводитись у реальній обстановці, в тій же послідовності, що є характерною для службових дій з охорони державного кордону, без пауз i перерв; коли кожне наступне навчальне питання $є$ продовженням попереднього.

Методика проведення комплексних практичних занять $з$ фахівцями прикордонного підрозділу передбачає таке:

Керівник підрозділу (за згодою вищого керівництва) має право змінювати (уточнювати) питання кожного комплексного заняття. Під час планування комплексних практичних занять потрібно визначити питання, які він у змозі відпрацювати, враховуючи обстановку на ділянці відповідальності, фізико-географічні умови служби та рівень підготовки фахівців. Про погодження нових питань робиться відповідна помітка у плані.

Під час складання розрахунку часу на відпрацювання кожного навчального питання, потрібно враховувати тривалість заняття, кількість навчальних питань і ступінь підготовленості фахівців.

Навчальні цілі заняття визначаються для кожної категорії прикордонників, а також підрозділу загалом, залежно від рівня підготовки фахівців та змісту теми заняття. Формування навчально-виховних цілей повинно бути конкретним, спрямованим на досягнення мети професійної підготовки, злагодження підрозділу в цілому, виховання у фахівців високих моральних якостей і психологічної стійкості. Для проведення заняття керівник розробляє тактичну обстановку на один ступінь вище для фахівців, які навчаються і проводять рекогносцировку району заняття. Рекогносцировка району заняття проводиться 3 метою уточнення тактичної обстановки, плану проведення заняття і порядку відпрацювання навчальних питань; уточнення розрахунку часу для відпрацювання кожного навчального питання, місця проведення розбору, порядок висування до місця проведення заняття і повернення в розташування; визначення порядку позначення дій «противника» (порушників законодавства) під час відпрацювання кожного навчального питання, перевірки підготовленості ділянки кордону (місцевості) до проведення заняття. Для того, щоб умови занять наблизити до реальної обстановки, що може виникнути, потрібно створювати обстановку високої напру- 
женості, прагнути, щоб фахівці прикордонного підрозділу постійно відчували вплив «противника» (порушників прикордонного законодавства). До позначення порушників прикордонного законодавства («противника») залучаються фахівці прикордонного підрозділу. Умовне позначення дій «противника» (порушників прикордонного законодавства) мішенями й імітаційними засобами доводиться до відома прикордонників. Дії «противника» (порушників прикордонного законодавства) ретельно маскуються для того, щоб фахівці отримали практику в їх виявленні і знищенні (затриманні). Після уточнення вихідних даних, проведення рекогносцировки і вивчення керівних документів керівник заняття розробляє план проведення комплексного практичного заняття в робочому зошиті або на схемі (карті). У плані проведення комплексного практичного заняття вказуються:

тема, навчальні та виховні цілі;

навчальні питання і порядок їх відпрацювання;

виділений час та місце проведення заняття;

тактична обстановка (вихідне положення, завдання відділенням, групам (прикордонним нарядам), відділенням (відділу) і сусідів;

дані про противника (порушників законодавства) та інші необхідні дані; порядок і зміст роботи керівника і фахівців;

матеріально-технічне забезпечення.

Після затвердження плану старшим начальником (не менш як за три доби до початку заняття) керівник заняття організує підготовку фахівців, озброєння, технічних засобів охорони кордону та іншої техніки, ділянки місцевості та матеріального забезпечення заняття.

Комплексні практичні заняття проводяться у складі структурного прикордонного підрозділу під керівництвом командира підрозділу, його заступників. На навчальних місцях (точках) - керівниками відділення, старшими інспекторами прикордонної служби та найбільш підготовленими інспекторами прикордонної служби першої категорії, мультиплікаторами за напрямами діяльності.

У складі відділення - під керівництвом заступників командира структурного підрозділу, начальника відділення. На окремих навчальних місцях (точках) - начальниками груп, старшими інспекторами прикордонної служби, підготовленими інспекторами прикордонної служби першої категорії, мультиплікаторами за напрямами діяльності. 
Підготовка фахівців до комплексного практичного заняття полягає у вивченні вимог Інструкції про службу прикордонних нарядів, сигналів взаємодії і управління, тактики дій порушників законодавства з прикордонних питань («противника»), інструкції щодо заходів безпеки; порядку застосування зброї та спеціальних засобів і заходів фізичного впливу; у підготовці озброєння, техніки, шанцевого інструменту, засобів захисту від зброї масового ураження та інших елементів екіпіровки; у вивченні нормативів, які будуть відпрацьовуватись на занятті, і в тренуванні їх виконання.

Напередодні заняття доцільно провести інструктивно-методичні заняття з помічниками (мультиплікаторами), які залучаються до проведення занять.

Також методика проведення комплексних практичних занять 3 фахівцями прикордонного підрозділу містить теоретичну частину. Так, для вивчення нормативно-правових актів (законів, постанов, наказів) та іншого теоретичного матеріалу організуються теоретичні, а за місцем проведення - класні заняття. Під час підготовки до заняття керівник повинен чітко визначитись, що повинен знати та вміти кожен фахівець, з якими питаннями їм потрібно ознайомитись і на що потрібно звернути увагу.

Також під час підготовки до заняття керівнику доцільно враховувати необхідність пропагування здорового способу життя як комплексу цільових організаційних і практичних заходів щодо популяризації таких форм і засобів повсякденної життєдіяльності фахівців, які вдосконалюють резервні можливості організму, сприяють успішному виконанню соціальних і професійних функцій, профілактику найбільш поширених захворювань.

Під час проведення теоретичних занять доводяться та роз'яснюються положення матеріалу, після цього надається час для вивчення теоретичних положень і проводиться опитування фахівців. Крім того наводяться позитивні та негативні приклади, що мали місце у прикордонних підрозділах. Водночас, для якісного проведення теоретичної частини заняття застосовують такі методи навчання: розповідь, пояснення, бесіда, показ (демонстрація).

У ході дослідження встановлено, що досить поширеним є проведення комплексного практичного заняття з виконанням практичних стрільб. 
Зважаючи на це, такі заняття організовуються, як правило, у складі зміни прикордонних нарядів. Керівник прикордонного підрозділу визначає мету заняття, готує помічників та навчальні місця, навчальну матеріально-технічну базу, організує підготовку зброї і спеціальних засобів.

3 фахівцями проводяться заняття з вивчення матеріальної частини зброї та заходів безпеки під час поводження з нею, які доводяться під підпис. Військовослужбовці, які не засвоїли правил та заходів безпеки, до стрільби та обслуговування не допускаються. Місцеві органи влади письмово попереджаються про дату, час та місце проведення стрільб.

Початок комплексного практичного заняття 3 виконанням практичних стрільб доцільно розпочинати з перевірки дій фахівців за сигналами. Після шикування фахівців керівник заняття перевіряє їх наявність, екіпіровку, озброєння та інші питання. Після усунення виявлених недоліків керівник заняття оголошує теми, мету та навчальні питання, а також порядок відпрацювання теми, навчальних питань. Далі він доводить тактичну обстановку, згідно якої будуть проводитися заняття, і ставить завдання фахівцям на висування до місця проведення занять. Висування фахівців на стрільбище доцільно починати з прискореного пересування на різні дистанції. Пересування проводиться відповідно до вимог порадника 3 фізичної підготовки. Якщо відстань до стрільбища значна, то фахівці, як правило, здійснюють марш-кидок комбіновано: частину маршруту на автомобілі, решту в пішому порядку (за наявності часу).

Під час висування в комплексі відпрацьовуються нормативи 3 фізичної підготовки, радіохімічної безпеки, екологічної безпеки та 3 інших напрямів підготовки.

3 прибуттям на стрільбище старший керівник вказує на місцевості вихідне положення, рубежі відкриття та припинення вогню, місце знаходження пункту боєпостачання, основні та небезпечні напрямки стрільби, ставить завдання фахівцям діяти залежно від умов вправи, яка виконується, нагадує про заходи безпеки під час проведення стрільб, здійснює інструктаж посадових осіб, які призначені для обслуговування стрільб, виставляє оточення. Перевіряє зброю, у тому числі і наявність патрона в патроннику. Додатково доводить заходи безпеки під час проведення стрільб.

Керівник прикордонного підрозділу під час виконання вправ стрільб є керівником стрільб на ділянці і виконує свої обов `язки від- 
повідно курсу стрільб. Для чіткої організації занять готується кілька навчальних місць, на яких можуть розглядатися інші питання з інших напрямів підготовки.

Методично доцільним та необхідним з позиції особистої безпеки фахівців є призначення на кожне навчальне місце керівника 3 числа офіцерів. Керівник прикордонного підрозділу проводить розрахунок фахівців та часу на навчальних місцях, вказує розташування навчальних місць, порядок відпрацювання навчальних питань, нагадує заходи безпеки на заняттях, дає команду на висування до вказаних навчальних місць. Зміна навчальних місць проводиться за командою старшого керівника стрільб.

У кінці заняття проводиться розбір заняття, перевіряється зброя в тому числі і наявність патрона в патроннику, набої (дається наказ про здачу невикористаних боєприпасів), навчальна матеріально-технічна база.

Вважаємо за доцільне зазначати, що важливим елементом методики професійної підготовки фахівців у прикордонному підрозділі є послідовність роботи офіцера під час підготовки до занять. Підготовка до занять передбачає: підготовку керівника занять, підготовку фахівців, підготовку місця проведення занять, підготовку матеріального забезпечення.

Підготовка керівника до занять містить з'ясування теми, їі змісту та виду заняття, визначення мети, навчальних питань і розрахунок часу для їх опрацювання; підбір і вивчення потрібної літератури і посібників; складання схеми (тактичного задуму), проведення заняття; вибір місця (району) проведення занять; проведення рекогносцировки району, під час якої уточняється задум, послідовність відпрацювання навчальних питань, проведення розрахунку необхідної навчальної матеріально-технічної бази, визначення складу помічників, та порядок їх підготовки до занять, об'єм робіт з підготовки місця проведення занять; складання плану конспекту.

Підготовка помічника керівника до занять містить 3'ясування теми, мети, навчальних питань і розрахунок часу для їх опрацювання; підбір і вивчення необхідної літератури; ознайомлення з місцем проведення занять; участь у проведенні рекогносцировки району, під час якої уточнює, послідовність та порядок дій під час відпрацювання навчальних питань, визначення необхідної навчально-матеріальної бази та об'єму робіт з підготовки місця проведення занять; складання плану конспекту. 
Професійна підготовка фахівців прикордонного підрозділу здійснюється з урахуванням обстановки, що складається, змісту виконуваних службових завдань. Навчальне навантаження на фахівців на тиждень складає до 8 годин: комплексне заняття - 3 тактики прикордонної служби - до 3 годин; комплексне заняття - 3 вогневої (тактичної) підготовки - до 3 годин; (комплексні заняття мають передбачати комплексне опрацювання питань 3 тактики прикордонної служби; тактичної, вогневої, фізичної, технічної, інженерної підготовок; радіаційної, хімічної, біологічного захисту та екологічної безпеки; тактичної медицини. При цьому матеріали напрямів підготовок (окремі питання) повинні логічно випливати 3 обстановки, на фоні якої проводиться заняття); фізична підготовка - 3 години (2 години під час комплексних занять); військово-ідеологічна підготовка - 1 година; спеціальна підготовка - 2 години ( під час обслуговування техніки). Заняття у прикордонному підрозділі проводяться щотижня у дні, визначені за рішенням керівника. Також з метою завчасної підготовки до виконання завдань 3 охорони кордону один раз за місяць проводяться тренування з пошуку і затримання навчальних порушників державного кордону.

Методика професійної підготовки фахівців у прикордонному підрозділі передбачає поточні та підсумкові перевірки, які проводяться у вигляді перевірки персоналу на професійну придатність виконувати службові обов'язки за посадою. Перевірка на професійну придатність проводиться за такими напрямами: спеціальна підготовка (містить теоретичний та практичний блоки), теоретична підготовка (містить блоки гуманітарної підготовки, психологічної підготовки та знання керівних документів) та практична підготовка (містить блоки фізичної, вогневої та екологічної підготовки, тренінги та тестування).

Установлюється єдина форма та періодичність контролю професійної підготовки. До виконання службових обов'язків за посадою фахівці допускаються в разі отримання задовільної індивідуальної оцінки з професійної підготовки. Військовослужбовцям, які отримали незадовільні результати, надається час для підготовки та повторного складання заліків. Щодо осіб, які не отримали допуск до виконання обов'язків за посадою, керівники підрозділів, приймають рішення про недопуск до самостійного несення служби у складі окремих видів прикордонних нарядів. 
Загальна оцінка рівня професійної підготовки підрозділу виводиться на підставі результатів перевірки на професійну придатність за такими критеріями: «відмінно» - якщо не менш як 95\% фахівців, які підлягали перевірці, виконали вимоги допуску до виконання службових обов'язків за посадою, 3 них понад 50\% фахівців отримали 3 професійної підготовки оцінки «відмінно»; «задовільно» - не більш ніж 25\%; «добре» - якщо не менш як 90\% фахівців, які підлягали перевірці, виконали вимоги допуску до виконання службових обов'язків за посадою, з них не менш як $60 \%$ персоналу отримали з професійної підготовки не нижче оцінки «добре»; «задовільно» - якщо не менш як 80\% фахівців, які підлягали перевірці, виконали вимоги допуску до виконання службових обов'язків за посадою; «незадовільно» - якщо не виконуються вимоги на оцінку «задовільно». Оцінка знижується на один бал, якщо більш як 10\% військовослужбовців підрозділу (за винятком тих, які перебувають у відпустці, відрядженні тощо) не проходили перевірку.

Загальну оцінку стану професійної підготовки відділів прикордонної служби підвищувати на один бал у разі, якщо у звітному періоді за результатами оперативно-службової діяльності підрозділ визнано кращим у регіональному управління. У разі, коли підрозділ за результатом перевірки на професійну придатність отримає загальну оцінку стану професійної підготовки «незадовільно», його фахівцям головою комісії буде надано право повторно складати залік. При цьому загальна оцінка стану професійної підготовки підрозділу може бути підвищена, але не вище оцінки «задовільно».

\section{4. Висновки та перспективи подалыших досліджень}

За результатами дослідження з'ясовано, що у сучасному науковому просторі проблема професійної підготовки фахівців різних галузей викликає значний інтерес; уточнено сутність поняття «професійної підготовки фахівців у прикордонному підрозділі як системи організаційних, навчально-педагогічних та практичних заходів, спрямованих на формування і розвиток у прикордонників професійно необхідних якостей, теоретичних знань та практичних навичок, що мають забезпечити високу готовність підрозділу до дій, їх злагодженість та високий професіоналізм в охороні державного кордону»; розроблено та обгрунтовано 
методику професійної підготовки фахівців у прикордонному підрозділі, яка становить сукупність методів. До основних методів професійної підготовки (навчання) фахівців у прикордонному підрозділі віднесено такі: розповідь, пояснення, бесіда, показ (демонстрація), вправа (тренування), практична робота, самостійна робота. Основною формою професійної підготовки фахівців у підрозділі, який безпосередньо охороняє державний кордон, $є$ комплексне (практичне) заняття.

Розроблення та обгрунтування методики професійної підготовки фахівців у прикордонному підрозділі дає змогу удосконалити іiї теоретичні та практичні аспекти. Цей напрямок $є$ перспективним для подальших наукових пошуків з проблеми. Також перспективним є детальне обгрунтування кожного із методів та визначення педагогічних умов професійної підготовки фахівців у прикордонному підрозділі.

\section{Список літератури:}

1. Татарін О. Формування готовності фахівців прикордонної служби до застосування заходів фізичного впливу в оперативно-службовій діяльності : дис. канд. пед. наук. Хмельницький, 2019. 291 с.

2. Тронь Т. Методичні рекомендації щодо вдосконалення професійної підготовки молодших фахівців Державної прикордонної служби України з урахуванням ідей досвіду Сполучених Штатів Америки. Збірник наукових пращь Начіональної академії Державної прикордонної служби Украӥни. Серія: Педагогічні науки. Хмельницький, 2017. № 3(10). С. 361-374.

3. Енциклопедия профессионального образования : в 3 т.; под ред. С. Батишева. Москва : АПО, 1999. Т. 2. 440 с.

4. Професійна підготовка. URL: https://uk.wikipedia.org/wiki/

5. Долинський Є. Професійна підготовка майбутніх перекладачів в умовах інформаційно-освітнього середовища університету : монографія. Хмельницький : ФОП Мельник А., 2018. 384 с.

6. Алєксєєва Г. Сутність і структура готовності майбутніх соціальних педагогів до застосування комп'ютерних технологій у професійній діяльності. Збірник наукових праць Бердянського державного педагогічного університету. Педагогічні науки. Бердянськ : БДПУ, 2012. № 2. С. 9-14. URL: http://bdpu.org/sites/bdpu.org/files/foipt/stat_Alekseeva_8.pdf

7. Інструкція з організації оперативно-службової діяльності відділу прикордонної служби Державної прикордонної служби України. Київ. Ч. І. 2009, 153 с.

8. Ставицький О. Теоретичні та методичні засади професійного виховання майбутніх офіцерів-прикордонників : монографія. Хмельницький : Видавництво НАДПСУ, 2014. 464 с.

9. Про удосконалення системи планування та обліку професійної підготовки : Наказ Адміністрації ДПСУ від 14 листопада 2018 року. № 103. 
10. Методичні рекомендації щодо організації та проведення заходів з професійної підготовки персоналу підрозділів ДПСУ. Хмельницький, 2016. 104 с.

\section{References:}

1. Tatarin O. (2019). Formuvannia hotovnosti fakhivtsiv prykordonnoi sluzhby do zastosuvannia zakhodiv fizychnoho vplyvu voperatyvno-sluzhbovii diialnosti [Formation of readiness of specialists of border service for application of measures of physical influence in operational and service activity]: dys. kand. ped. nauk. Khmelnytskyi, 291 p.

2. Tron T. (2017). Metodychni rekomendatsii shchodo vdoskonalennia profesiinoi pidhotovky molodshykh fakhivtsiv Derzhavnoi prykordonnoi sluzhby Ukrainy z urakhuvanniam idei dosvidu Spoluchenykh Shtativ Ameryky [Methodological recommendations for improving the professional training of junior specialists of the State Border Guard Service of Ukraine in the light of the ideas of the experience of the United States of America]. Zbirnyk naukovykh prats Natsionalnoi akademii Derzhavnoi prykordonnoi sluzhby Ukrainy. Seriia: Pedahohichni nauky. Khmelnytskyi. № 3(10), pp. 361-374.

3. Entsyklopedyia professyonalnoho obrazovanyia (1999): v 3 t.; pod red. S. Batysheva. Moskva: APO. T. 2. 440 p.

4. Profesiina pidhotovka [Professional training]. URL: https://uk.wikipedia.org/wiki/

5. Dolynskyi Ye. (2018). Profesiina pidhotovka maibutnikh perekladachiv v umovakh informatsiino-osvitnoho seredovyshcha universytetu: monohrafiia [Professional training of future translators in the context of the university's information and educational environment: a monograph]. Khmelnytskyi: FOP Melnyk A., 384 p.

6. Alieksieieva H. (2012).Sutnist i struktura hotovnosti maibutnikh sotsialnykh pedahohiv do zastosuvannia kompiuternykh tekhnolohii u profesiinii diialnosti [The essence and structure of future social educators' readiness to use computer technology in their professional activities]. Zbirnyk naukovykh prats Berdianskoho derzhavnoho pedahohichnoho universytetu. Pedahohichni nauky. Berdiansk: BDPU. № 2, pp. 9-14. URL: http://bdpu.org/sites/bdpu.org/files/foipt/stat_Alekseeva_8.pdf

7. Instruktsiia $\mathrm{z}$ orhanizatsii operatyvno-sluzhbovoi diialnosti viddilu prykordonnoi sluzhby Derzhavnoi prykordonnoi sluzhby Ukrainy (2009). [Instruction on organization of operational and service activities of the Border Service of the State Border Service of Ukraine]. Kyiv. Ch. I. 153 p.

8. Stavytskyi O. (2014). Teoretychni ta metodychni zasady profesiinoho vykhovannia maibutnikh ofitseriv-prykordonnykiv: monohrafiia [Theoretical and methodological foundations of the professional training of future border guards: a monograph]. Khmelnytskyi: Vydavnytstvo NADPSU, $464 \mathrm{p}$.

9. Pro udoskonalennia systemy planuvannia ta obliku profesiinoi pidhotovky [On improvement of the system of planning and accounting of vocational training]: Nakaz Administratsii DPSU vid 14 lystopada 2018 roku. № 103.

10. Metodychni rekomendatsii shchodo orhanizatsii ta provedennia zakhodiv z profesiinoi pidhotovky personalu pidrozdiliv DPSU (2016). [Guidelines for organizing and conducting training events for the staff of the SBSU units]. Khmelnytskyi, $104 \mathrm{p}$. 